\title{
SCIENTIFIC REPORTS

\section{A chronology of landsliding based on archaeological and documentary data: Pavlovské vrchy Hills, Western Carpathian Flysch Belt}

\begin{abstract}
Michal Bíl $\mathbb{1}^{1 *}{ }^{1 *}$, Oldřich Krejčí ${ }^{2}$, Lukáš Dolák ${ }^{1}$, Vladimíra Krejčí ${ }^{2}$, Jan Martínek ${ }^{1}$ \& Jiří Svoboda ${ }^{3,4}$
Pavlovské vrchy Hills represent a distinctive elevation near the Czech-Austrian border where the active, dormant and relict landslides cover $12 \%$ of the area. Here we focused on the chronology of landsliding in this area using geological, archaeological and historical evidence. The earliest records of landsliding were determined in locations underlying the dated archaeological settlements. The Upper Paleolithic settlement complex dated between 37-24 ka cal BP, was originally deposited over these landslides. It was consequently destroyed in certain places by additional landslides preceding the last (Upper Pleniglacial) loess deposition (22 ka cal BP). These landslides took place before and after the Upper Paleolithic occupation of this area. This Pleistocene landslide event ranks among the oldest (albeit indirectly) dated landslide within the Czech part of the Western Carpathian Flysch Belt. The chronology of later, historical, landsliding was determined using written records (chronicles, official reports, archival evidence, etc.). Continuous records of landsliding were available as of the middle of the seventeenth century. The major concentration of landslides occurred at the beginning of the twentieth century (1910-1915). The 1663 landslide is currently the oldest landslide, in the Czech part of the Western Carpathian Flysch Belt, which was dated on the basis of documentary data.
\end{abstract}

The Western Carpathian Flysch Belt (WCFB) ranks among the areas most susceptible to landsliding in the Czech Republic $^{1-5}$. As many as 15,215 landslides, representing 75\% of all landslides registered within the entire Czech Republic (CR), can be found in the Czech part of the WCFB $\left(6,465 \mathrm{~km}^{2}\right)$. Holec et al. ${ }^{6}$ claimed that the ratio of landslide-affected areas in the entire WCFB is $13.6 \%$. Certain local studies, conducted in the Czech part of WCFB, presented even higher numbers, up to $20 \%^{7}$.

Many types of landsliding can be found in the Czech WCFB, e.g. shallow landslides ${ }^{3,8}$, debris flows , $^{9,10}$, deep-seated landslides ${ }^{2,11-13}$, rockfalls ${ }^{14-16}$ or complex flow-like landslides ${ }^{9,10,17}$. A number of slopes in the highest parts of WCFB were also affected by DSGSD [e.g. ${ }^{11,18,19}$ ].

\section{Current Research on Landslide Dating in the Czech WCFB}

Pleistocene landslides. The vast majority of dated landsliding in the Czech part of WCFB are from the Holocene age. The inventory of the dated WCFB landslides with new radiocarbon dates (from woody and other organic remnants within the landslide body or from lakes on the landslide surface) allowed for the identification of landslide phases in the Holocene ${ }^{20}$. The results of dating the slope movements by the ${ }^{14} \mathrm{C}$ determination method in the Czech WCFB have yielded so far results from the youngest phase of sliding in the Holocene ${ }^{17}$. Pánek et al ${ }^{17}$ reported the results of dating from 13 localities ranging from 12.86-9.30 ka (Kykula locality; cal BP) to 510-470 years (Pluskovec locality; cal BP). Virtually, these data fall mostly into the Holocene period (0-11.734 ka cal BP).

Many well-known, large-scale landslides occurring in Czech WCFB still have not been dated, however. The primary cause of the lack of dating of these pre-Holocene landsliding here is the intensive erosion of the oldest landslide forms. Exceptions include the slopes of Kabátice in the Moravskoslezské Beskydy Mts. (around 51-56 $\mathrm{ka}$ cal BP with a continuation until $<36 \mathrm{ka} \mathrm{cal} \mathrm{BP}^{21}$ ); and the Malenik Ridge in the Moravian Gate ${ }^{22}$, where the Upper Pleistocene mass movements $(47,704 \pm 2346 \mathrm{cal} \mathrm{b2k})$ were dated.

${ }^{1}$ CDV - Transport Research Centre, Líšeňská 33a, 636 00, Brno, Czech Republic. ${ }^{2}$ Czech Geological Survey, Klárov 3, 118 21, Prague, Czech Republic. ${ }^{3}$ Faculty of Science, Masaryk University, Kotlářská 267/2, 611 37, Brno, Czech Republic. ${ }^{~ I n s t i t u t e ~ o f ~ A r c h a e o l o g y, ~ A c a d e m y ~ o f ~ S c i e n c e ~ o f ~ t h e ~ C z e c h ~ R e p u b l i c, ~ 69129, ~ D o l n i ́ ~ V e ̌ s t o n i c e, ~ C z e c h ~}$ Republic. *email: michal.bil@cdv.cz 


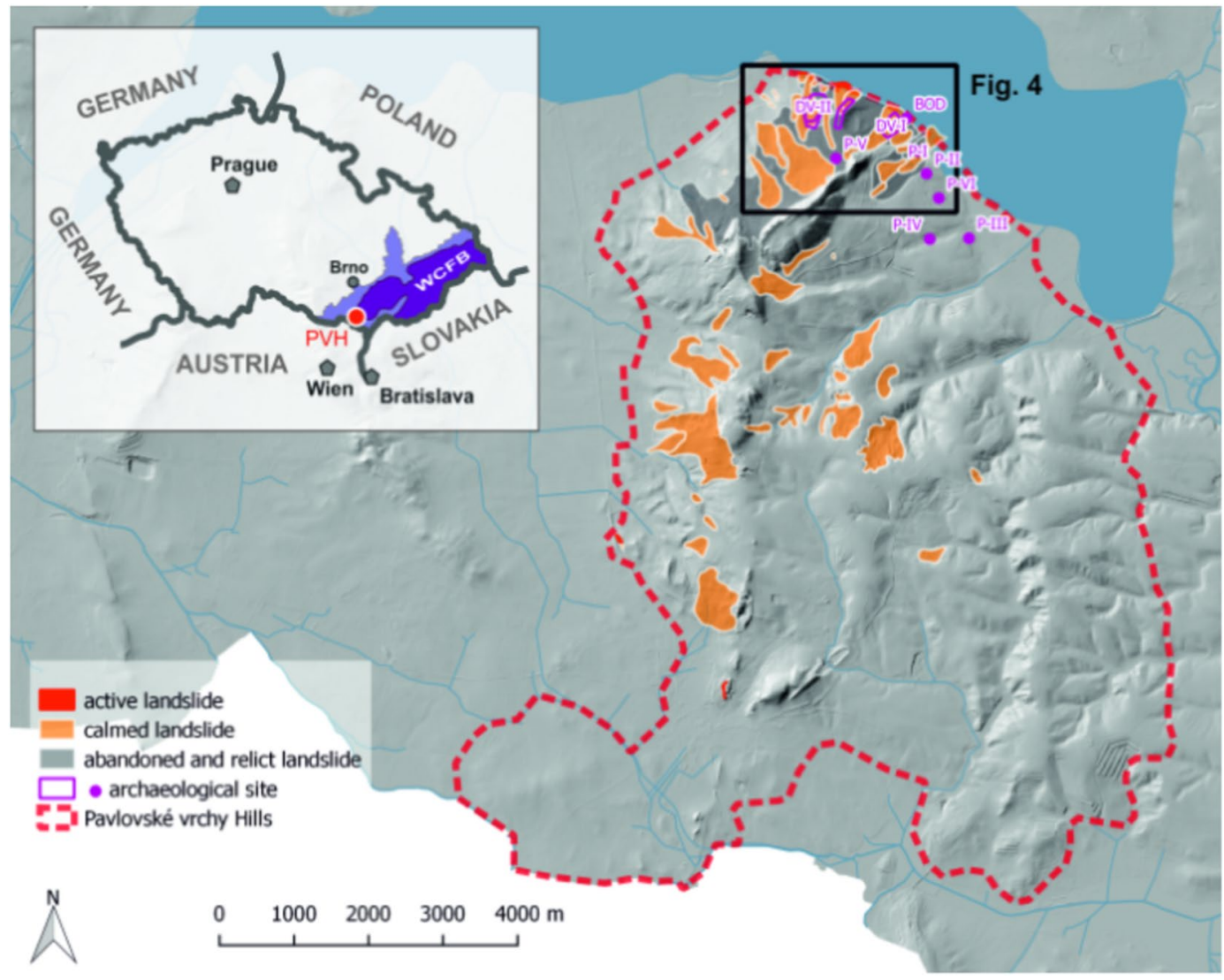

Figure 1. Pavlovské vrchy Hills (PVH) and its position within the Czech Republic and WCFB. Processed in QGIS Version 2.18.0 'Las Palmas'.

Historical landslides. The general lack of suitable materials for landslide dating using geochronological methods, even among the youngest landslides, lead to utilization of other methods in WCFB, e.g. dendrochronological ${ }^{16}$. The existence of written documents (and related references to the current weather therein) has already been utilized by historical climatologists. Research focusing on landsliding which were active during historical times can also utilize this data. Špurrek ${ }^{23}$ provided the first comprehensive overview of dated landslide events with this method which covered the area of Central Europe, but also contained records from other parts of the world. The primary sources of his work were newspapers and historical documents. Several episodes of intensification of mass movements were identified in this work in WCFB (e.g. $\left.{ }^{23}\right)$. The most recent $(1939,1941,1970,1997,2006$ and 2010) were identified from the village of Halenkovice and its vicinity (approx. $70 \mathrm{~km}$ NE from Pavlovské vrchy Hills ${ }^{7}$ ); An example of a landslide episode with a large spatial extent (e. g. the entire area of the CR and its vicinity) is that which took place in the spring of $1941^{7,23-25}$. Other historical documentation of landslide events, over more than the last 200 years, was conducted by Raška et al. ${ }^{26,27}$.

In this paper, which combines geological, archaeological, and historical records, we present evidence from the Pavlovské vrchy Hills for repeated landsliding which affected human settlements. We also synthetized data and built a chronology of landsliding for this part of the Czech WCFB from prehistory to the recent times. This area (located in Moravia, i.e., eastern part of CR; Fig. 1) has been systematically surveyed by archaeologists as of the 1920s. Landslides were mentioned a number of times along with the abundant archaeological findings ${ }^{28-30}$. It was also inhabited up until the end of World War II by a German population which carried out detailed reports, often mentioning natural processes, in their chronicles. Such systematic observations, including reports on landsliding, are not available for the rest of the Czech WCFB until the first quarter of the twentieth century.

Geological and geomorphological setting. The topography of this area is strongly affected by the presence of relatively hard limestone which overhangs the neighboring weak flysch rocks forming a rather flat relief (Fig. 2). The Pavlovské vrchy Hills exceed the neighboring landscape up to $350 \mathrm{~m}^{31}$. The Hills are mainly built up by the rootless, tectonically transported, sediments of the lowermost unit of the WCFB nappe stack. They consist of numerous imbricates, duplexes, and partial thrust sheets of the Upper Jurassic to Lower Miocene strata. Tectonic klippen of Jurassic marls and carbonates and Upper Cretaceous (Turonian to Campanian) clastic rocks are tectonically incorporated into the thrust sheets of the younger, Paleogene to Lower Miocene sequences (Fig. 3).

The Pavlovské vrchy Hills make up part of the exterior Menilithic-Krosno Group of nappes of the WCFB. The area around Dolní Věstonice, built up of pre-Quaternary calcareous claystones, sandstones, and rare 


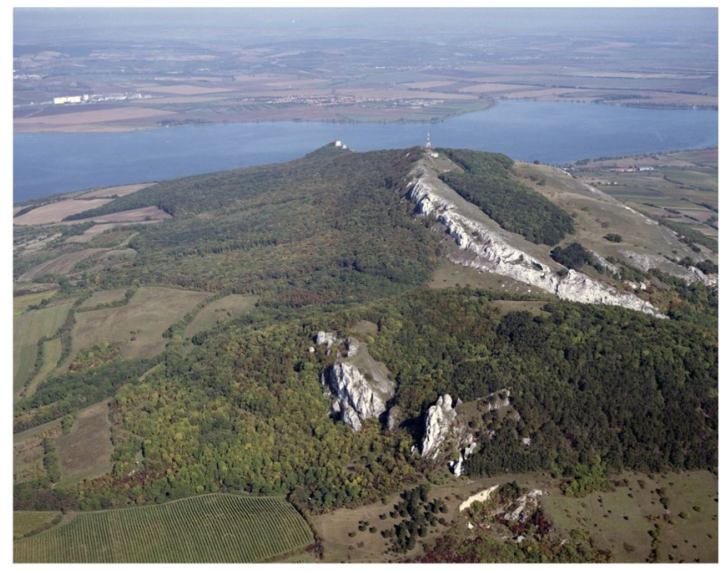

Figure 2. The Pavlovské vrchy Hills form a distinct dominant in a generally flat terrain which attracted Paleolithic humans for settlement. Photo Jan Vondra, Aerofot Brno.

conglomerates, belongs to the Pouzdřany unit and mainly to the Waschberg - Ždánice units ${ }^{32,33}$. Waschberg Ždánice units are the major frontal thrust system of the WCFB.

The area was the subject of erosion and denudation in the Late Miocene after the WCFB moved to its present position. Limestone bodies form an anticlinal nappe structure protruding from the surrounding, mostly claystone strata. It is a geological structure, typical for the Pavlovské vrchy Hills and disturbed by vertical fault tectonics, which resulted in the sliding of large block along the claystone surface. Pleistocene denudation and accumulation processes on the NW slopes of the Pavlovské vrchy Hills led to a complicated lithostratigraphic sequence, often disturbed by sliding. The block-stony rubble colluvium with the soil-clay matrix created large landslides that slid down the slopes. These landslides resulted in the next disintegration and a mixing of the material on the slopes arose and arises under appropriate climatic conditions, earthflows with devastating effects to both prehistoric settlements and modern villages.

Evidence of this process are the limestone blocks found in the riverbed of the Dyje River ${ }^{28}$. The role of bedrock and its structure in WCFB as a factor of landslide origin was investigated by Rybá ${ }^{34}$ who defined the typical case situations. The common pattern in the WCFB is the alteration of inclined rigid and plastic beds. It has been demonstrated that flysch slides commonly originate on slopes determined by downslope bedding.

The Quaternary cover of the Pavlovské vrchy Hills consists of fluvial sandy gravels of the Dyje River in several terraces (fluvial accumulations), colluvial slope sediments and aeolian sediments. During the warm interglacial and shorter interstadial periods of the Pleistocene, the fossil soils and their derivates (soil sediments) were formed in the aeolian sediments. Later, in the Holocene, the subfossil soils were developed in fluvial sandy loams (flood loam). This evidence illustrates the complicated geological evolution over the entire Quaternary in the last $2.588 \mathrm{Ma}$ (www.stratigraphy.com; and ${ }^{35,36}$ ).

Prehistoric and historical settlement of the pavlovské vrchy hills. Pleistocene. Although the earliest dated archaeological artifacts in the Pavlovské vrchy Hills belong to the Early Upper Paleolithic (probably Aurignacian), here we focus on the subsequent Middle Upper Paleolithic (Gravettian), the most extensive and the best dated archaeological unit.

Within the key regional section DV 09, found at the bottom of site DV II, (known as "brickyard" or "Calendar of Ages") covering the complex sequence of Upper Pleistocene loess, paleosols, and colluvia, the archaeological layer was dated by $\mathrm{C}^{14}$ between $30,553-29,442 \mathrm{cal} \mathrm{BP}{ }^{37}$. This layer also corresponds to an extensive Upper Paleolithic archaeological complex excavated over the last century at the Dolní Věstonice and Pavlov sites by Karel Absolon, Assien Bohmers, Bohuslav Klíma and Jiř́ Svoboda $\left(\operatorname{se}^{28,38,39}\right)$.

These archaeological excavations provided 6 radiocarbon dates from the site of DV I ${ }^{40}, 37$ dates from DV $\mathrm{II}^{41}$, and 30 dates from Pavlov ${ }^{42}$. The majority of these dates were measured at Groningen and Oxford Radiocarbon Laboratories and calibrated after OxCal v.4.2., using IntCal13 calibration curve ${ }^{43}$. These dates are also supported by a series of OSL dates from DV II ${ }^{41,44}$ and, most recently, by direct radiocarbon dates obtained from human fossils found at the same site and measured at the Aix-en-Provence Laboratory ${ }^{45}$. All these dates provide a consistent record of human occupation during the MIS3 period. In terms of microchronology, the dates place a scarce Early Upper Paleolithic (probably Aurignacian) occupation at several discrete spots at DV II and Pavlov I dated between 37-33 ka cal BP, followed by the dominant early Gravettian occupation at all sites between 33-29.5 $\mathrm{ka} \mathrm{cal} \mathrm{BP}$, and by scarce evidence of the late Gravettian between 29.5-24 ka cal BP. At the sites of DV I, II, and Pavlov I, evidence of landsliding is documented both below and above the archaeological deposits. During the Last Glacial Maximum (a period culminating around $22 \mathrm{ka} \mathrm{cal} \mathrm{BP;} \mathrm{see}{ }^{46,47}$ ), evidence of human settlements disappeared. The cultural layers and the evidence of landsliding were superposed by archaeologically sterile "Upper Pleniglacial Loess" ${ }^{48}$. The thickness of the Upper Loess layer in the Dolní Věstonice section DV 09 is about $5.8 \mathrm{~m}^{37,49}$. According to the optically stimulated luminescence (OSL) method of dating, the "Upper Pleniglacial Loess" sedimentation in DV 09 took place between $27-20 \mathrm{ka}$ cal BP ${ }^{37,44}$. This loess can be used for determining the age of the earlier slide movements that disturbed underlying Gravettian cultural layer. 


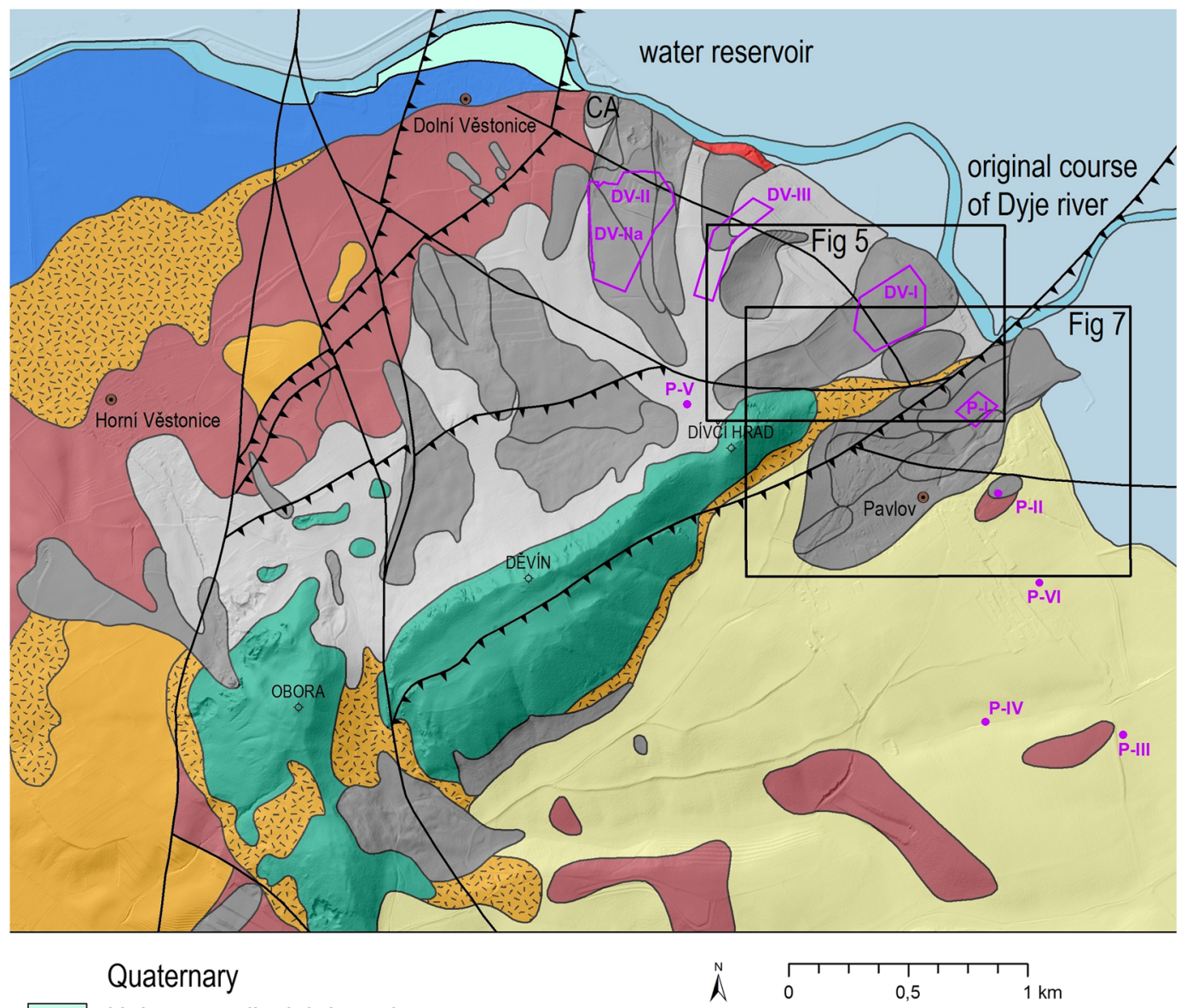

\section{Holocene, alluvial deposits \\ Holocene - Pleistocene, colluvial deposits \\ Pleistocene, terrace level \\ Pleistocene, loess, loess loam}

\section{Western Carpathians, Carpathian Foredeep Lower Miocene sediments}

\section{Western Carpathians, Flysch nappes Paleogene, Pouzdrany and Ždánice units Mesozoic, Ždánice unit, carbonates}

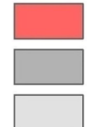

active landslide calmed landslide relict landslide CA calendar of ages

- fault $\ldots$ thrust fault

- $\square$ archeological site

Figure 3. A geological map of the northern part of the Pavlovské vrchy Hills, which is bordered by a water reservoir to the north. Processed in ArcGIS 10.6.1 for desktop.

Holocene. In contrast to the Pleistocene, evidence of the Holocene human settlement of the same area was continuous. It starts with the Mesolithic Period (11.0-7.5 ka cal BP). Neolithic farmers from the Middle East followed as of $8 \mathrm{ka} \mathrm{BP}^{50}$. After the Neolithic Period; about 7.5-6.3 ka BP and the Eneolithic Period (about 6.3-4.0 ka BP) the Pavlovské vrchy Hills became one of the most populated areas in Moravia ${ }^{51}$ in the Bronze Age (4.0-2.7 $\mathrm{ka} \mathrm{BP}$ ) and early Iron Age of the Hallstatt Period (2.7-2.4 ka BP). The La Tene (Celtic) Period inhabited this area for four centuries (about 2.4-2.0 ka BP) and during a short period (about $2.0 \mathrm{ka} \mathrm{BP}$ ) was replaced by a German tribe of Suebi. It should be pointed out that a Roman military camp was located northwest of the Pavlovské vrchy Hills and dated to $1.8 \mathrm{ka} \mathrm{BP}{ }^{52}$. At the beginning of the Migration Period (1.6 ka BP), most of the population of the Suebi tribe left and the Lombards inhabited the abandoned area. Already about $1.4 \mathrm{ka} \mathrm{BP}$, however, the Lombards were replaced by Slavic people building several fortified settlements ${ }^{53}$. The area of the Pavlovské vrchy Hills went through a florescence about $1.1 \mathrm{ka} \mathrm{BP}$ as part of the powerful Great Moravia Empire. As of $0.7 \mathrm{ka}$ BP, most of the current villages and towns existed, although some of them perished or were relocated over the following centuries. The main reasons for moving the villages, usually further from the rivers, was deforestation and more frequent floods ${ }^{54}$. At the same time, i.e. seven hundred years ago, the colonization of Germans to this area began and brought about an important German influence (language, skills, etc.). The number of documentary evidence 


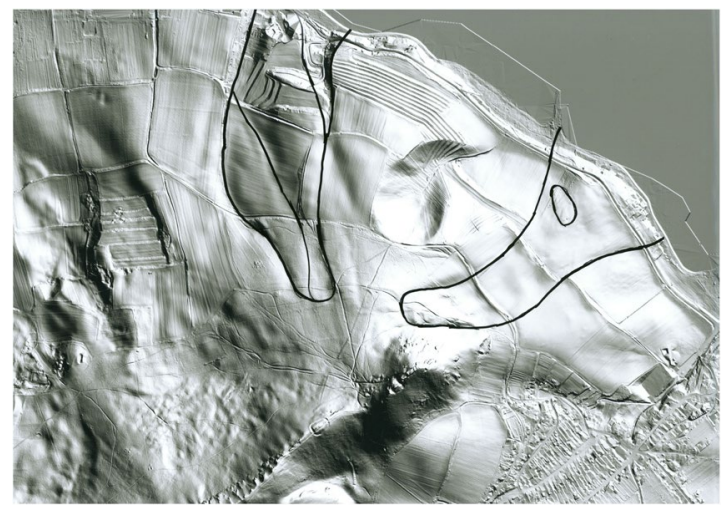

Figure 4. A detailed LiDAR picture where numerous tracks of landsliding can be identified. The conspicuous ridge in the central part is formed by Jurassic limestones and is a frequent source of landsliding and rockfalls.

increased since that time. German settlements stopped with the end of World War II in $1945^{55}$. The population density over history fluctuated depending on wars, famine or diseases (e.g. the Thirty Years' War, 1618-1648).

\section{Data and Methods}

Documentary data. We used available historical data such as written records (chronicles, official reports, archival evidence etc.), newspapers, maps and photographs. This data was complemented by secondary sources (early scientific papers, the history of towns and villages, etc.). This kind of data allowed us to localize landsliding in terms of spatial and temporal accuracy. A number of documentary records were hand-written in Neo-Gothic italic script in German (in more recent times also in Czech). The terminology of landslides included a rich variety of terms: "Rutschung" [slide], "Erdrutschung" [landslide], "Erdrutsch" [sliding], "Einsturz" [slump] or "Senkung" [decline]. The information related to landslides was carefully transliterated and excerpted. Where possible, individual records were checked by cross-referencing to other evidence. Individual events, dates of occurrence (if they were available), the type of affected property, and the extent of damage and source of data became the basic information for further critical analyses and interpretations. The primary limitation when dating historical landslides in WCFB is the lack of available resources. Documentary data (chronicles, official reports, archival evidence, etc.) are only seldom available before the nineteenth century.

LiDAR and digital elevation model data. Current geological maps, reports of geophysical investigation and actual LiDAR data (digital elevation model) were used in order to delineate the actual extent of landsliding in the Pavlovské vrchy Hills (Fig. 4). Slope deformations known in the study area are mainly typical landslides, earth or debris flows ${ }^{56}$ and vast, complex slope deformations up to many hundreds of metres in length ${ }^{12,57}$.

Engineering-geological survey data. An engineering-geological survey related to the construction of Nové Mlýny water reservoirs was completed in 1967. These works ${ }^{58}$ provided data on the extent and depth of landslides related to the archaeological sites. Construction of the water reservoir took place between 1981 and 1988. The water in the reservoir has been in direct contact from that time with the frontal part of the slope instabilities (Fig. 3).

\section{Results}

Landslides identified on the basis of archaeological data. An extensive complex landslide with the archaeological site DV I $28,29,38,40$ was a key locality for the reconstruction of the Upper Pleistocene slope movements. The development of mapping and knowledge about this landslide and individual archaeological excavations are shown in Fig. 5. The existence of several isolated settlements, located within the DV I archaeological site, determines that this area was inhabited and abandoned several times. Klíma ${ }^{29}$ suggested that this landslide area was selected to establish a Gravettian settlement as the wavy terrain included water springs, platforms suitable for building shelters, and a depression for bone and waste disposal.

Further local migrations of prehistoric hunters within the Pavlovské vrchy Hills could have been caused by partial activation of slope movements. Knor et al. ${ }^{28}$ have drawn valuable profiles through the partial walls of older archaeological excavations (already destroyed today), which unequivocally demonstrated the destruction of cultural layers by sliding movements (see Fig. 6). Moreover, in the same publication, it was stated that loess layers were stacked by sliding processes to 5-6 slices, which apparently caused superposition of 5 to 6 culture layers, one above another. This profile demonstrated that the slope movements that had affected the cultural layer were gradually completed during sedimentation of the Upper Pleniglacial loess. Determination of age of this last loess deposition was crucial for dating of the landsliding which affected and consequently destroyed Gravettian settlements. Excavation at the same site later yielded additional sections documenting a landsliding stage between the deposition of the cultural layer and the uppermost loess ${ }^{40}$.

The above-mentioned Upper Pleistocene landslides in all probability only rejuvenated much older rotationally-translational rupture zones. Flysch sediments of the Ždánice unit (WCFB) were transported in 


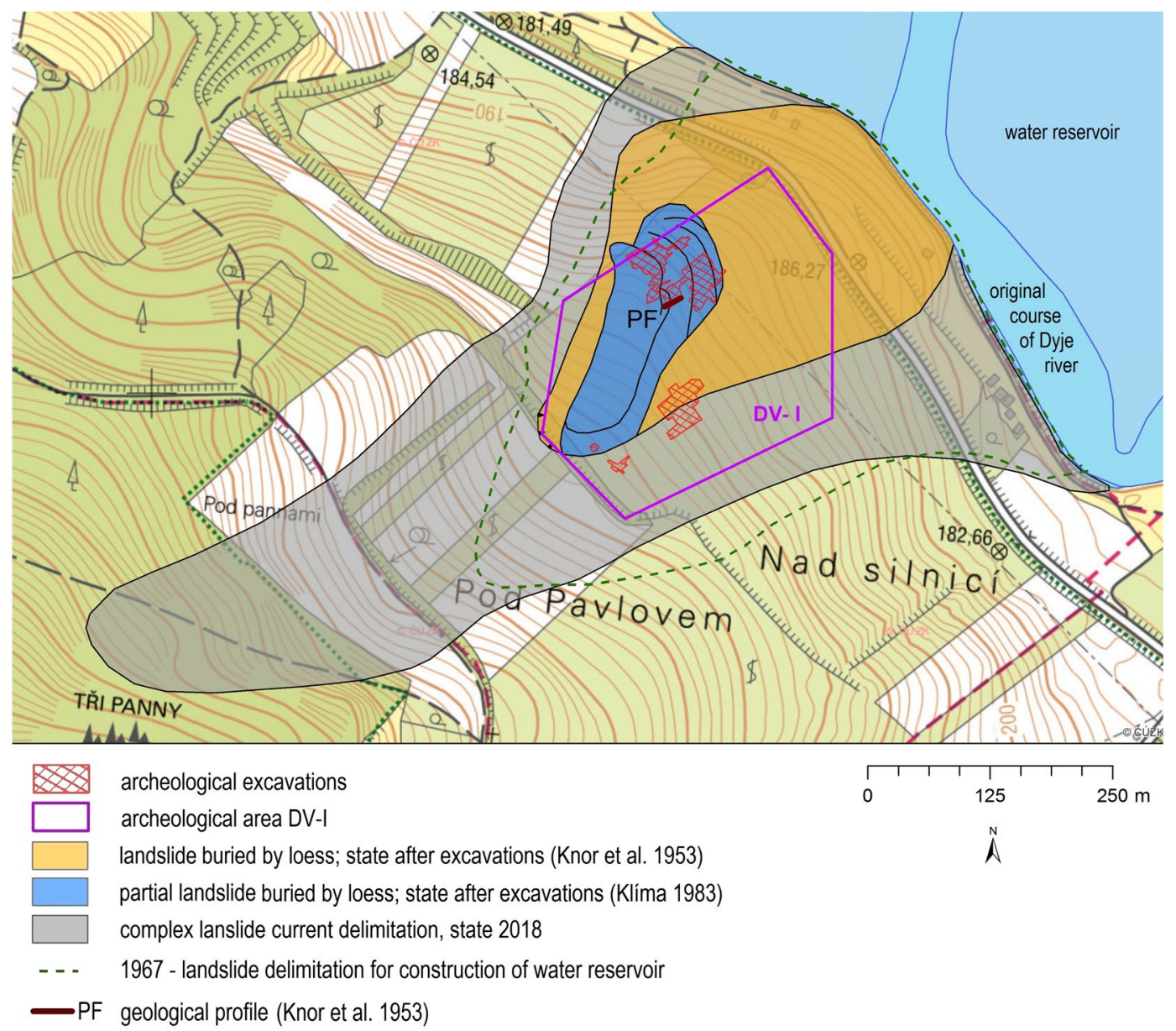

Figure 5. Landslide in the broader area of archaeological site DV I with a history of mapped boundary changes and dated findings. Processed in ArcGIS 10.6.1 for desktop.

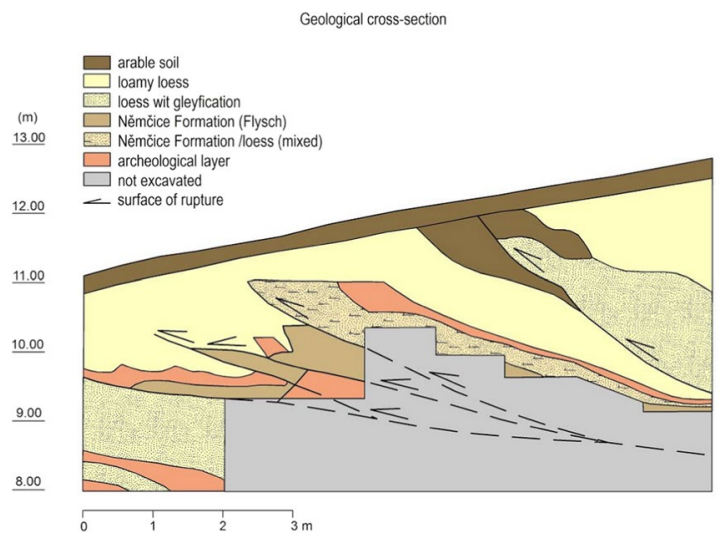

Figure 6. Excavation wall from 1947 with evidence of disturbance of the Gravettian archaeological layer due to slope deformations. Adapted after Knor et al..$^{28}$.

several phases almost to the surface along these sliding surfaces. These large landslides are therefore even older than the beginning of the Gravettian settlements.

Landslides identified on the basis of documentary data. We found a written reference to the oldest landsliding in the Pavlovské vrchy Hills (Pavlov village in 1663; Fig. 7) in a book by Maca ${ }^{59}$ who compiled information on local life from the original German chronicles. This 1663 event thus presents the oldest record of 


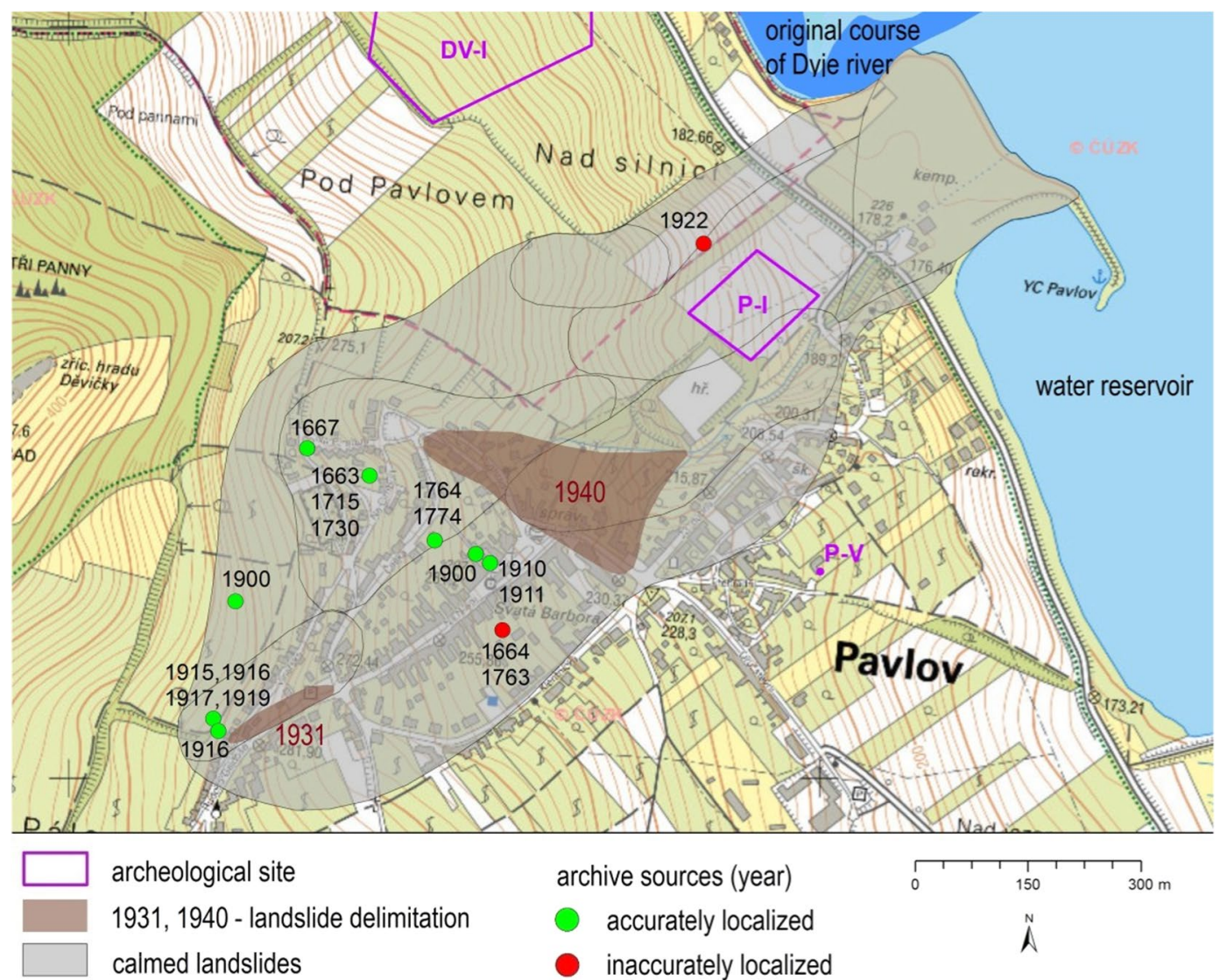

Figure 7. Pavlov village, the most frequently affected place by landsliding, at the Pavlovské vrchy Hills. Processed in ArcGIS 10.6.1 for desktop.

landsliding based on the documentary data in WCFB in CR. There are only 3 older records, identified using the same technique, all located in the western part of CR. They took place during the sixteenth century ${ }^{23}$.

The database on landsliding (Table 1), which took place between 1663 and 1941, at Pavlovské vrchy Hills currently contains 30 events which occurred in 19 years in six villages. Many individual landslides were reactivated several times, but it was not always possible to distinguish reactivation from the emergence of new landsliding and identification of their precise positions was not always possible.

Impacts of landsliding on local society. It was clear, from the available archaeological evidence, that the settlements of mammoth hunters were destroyed several times by landsliding. They therefore had to change their home for a number of times as also documented from archaeological data.

Concerning the historical landslides, they were not usually reported, if they did not cause any economic losses. As many as 30 landslides were identified between 1663 and 1941 in this area (Table 1). Pavlov village was the most frequently mentioned place (17-times) in term of landslide losses. Landslides also destroyed pseudokarst caves. This occurred in Dolní Dunajovice village in the winter of 1919-20 where a pseudokarst cave roof collapsed as a result of landsliding ${ }^{60}$.

Špurrek ${ }^{23}$ reported 15 cases of landsliding, with the oldest from 1906. Other landslides, as well as the previously mentioned by Špůrek ${ }^{23}$, were recorded by local documentary resources and early scientific works. The smallest number of reports about a landslide was one (1667, 1770 - Pavlov, 1900 - Mikulov, 1911 - Dolní Věstonice, 1919 Dolní Dunajovice and 1941 - Pavlov), while other landslides were mentioned at least twice. Four references were available for landslides in 1774, 1900 and 1916. One landslide, which should have taken place in 1836 near Perná village $^{61}$, can be clearly visible from a map from $3^{\text {rd }}$ Military survey which was prepared in the 1870 s.

At least eight houses, ten farm buildings and seven cellars were completely destroyed over the 1663-1941 period. Another 17 buildings and 12 cellars were spoiled by landsliding. The oldest detailed description can be determined for spring $1774^{59,62,63}$. Other reports come from $1830^{64}$. Part of a clay quarry close to Dolní Věstonice was affected by landsliding in $1906^{65}$ (Fig. 8). Exceptionally wet weather in 1910 caused many landslides in January 1911. Two houses were completely destroyed in Pavlov in 1911 and many gardens deformed and moved up to $50 \mathrm{~m}$ downslope ${ }^{63}$. Another phase of landsliding took place between 1915 and 1917 when cracks were registered in almost all the buildings in Pavlov village, including the church and 15 houses and 11 cellars were destroyed $^{62}$. The last intensification of landsliding was registered in 1941 when 3 cellars were destroyed, and many vineyards were damaged ${ }^{59}$. The above-mentioned landslide chronology can be compared to those previously published for $\mathrm{WCFB}^{7}$. 


\begin{tabular}{|c|c|c|c|c|}
\hline Year & Month & Season & Municipality & Wet year* \\
\hline 1663 & - & - & Pavlov & No \\
\hline 1667 & - & - & Pavlov & No \\
\hline 1715 & - & - & Pavlov & No \\
\hline 1730 & - & - & Pavlov & No \\
\hline 1763 & - & - & Pavlov & No \\
\hline 1770 & - & - & Pavlov & Yes (Jun 1770) \\
\hline 1774 & - & Spring & Pavlov & No \\
\hline 1830 & - & Spring & Pavlov & No \\
\hline 1836 & - & - & Perná & Yes \\
\hline 1900 & - & Spring & Pavlov & locally yes \\
\hline 1900 & - & Spring & Mikulov (Turold) & locally yes \\
\hline 1906 & - & - & Dolní Věstonice & No \\
\hline 1910 & - & Spring & Pavlov & Yes \\
\hline 1911 & Jan & Winter & Klentnice & Yes (1910) \\
\hline 1911 & Jan & Winter & Mikulov (Turold) & Yes (1910) \\
\hline 1911 & Jan & Winter & Pavlov & Yes (1910) \\
\hline 1911 & Jan & Winter & Perná & Yes (1910) \\
\hline 1911 & Jan & Winter & Dolní Věstonice & Yes (1910) \\
\hline 1915 & - & Autumn & Pavlov & Yes (Oct) \\
\hline 1915 & - & Autumn & Klentnice & Yes (Oct) \\
\hline 1915 & - & Autumn & Mikulov (Turold) & Yes (Oct) \\
\hline 1916 & Jun & Spring & Pavlov & Yes (Jun) \\
\hline 1916 & - & Spring & Mikulov (Turold) & Yes (Jun) \\
\hline 1917 & - & - & Pavlov & No \\
\hline 1919 & - & - & Pavlov & Yes (Nov) \\
\hline 1919 & - & - & Klentnice & Yes (Nov) \\
\hline $1919 * *$ & - & Winter & Dolní Dunajovice & Yes (Nov) \\
\hline 1922 & - & Spring & Dolní Věstonice & No \\
\hline 1922 & - & Spring & Pavlov & No \\
\hline 1941 & - & - & Pavlov & Yes \\
\hline
\end{tabular}

Table 1. Landslides at the Pavlovské vrchy Hills between 1663 and 1941. Dating based on documentary data. *Information about wet years derived from ${ }^{66}$. Data were further checked using the following works ${ }^{67,68}$ and information in local chronicles. **Destruction of pseudokarst cave roofs on Liščí kopec hill.

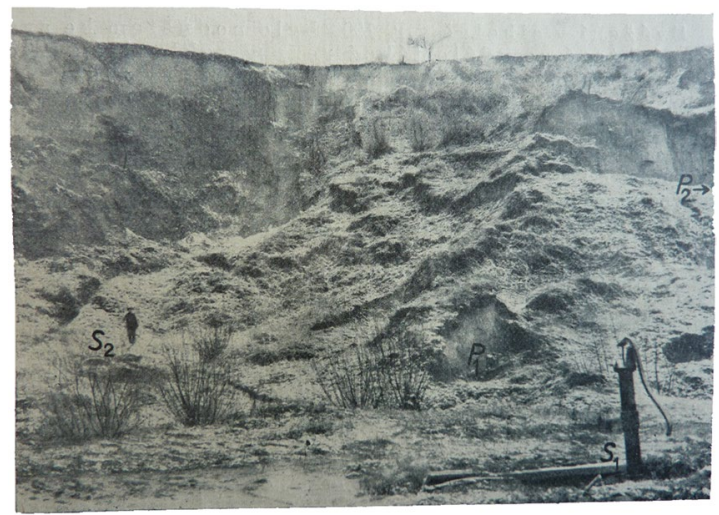

Figure 8. The 1906 landslide near Dolní Věstonice village. Photo from Woldřich and Stejskal ${ }^{65}$.

\section{Discussion}

We presented the chronology of landsliding, for an area in the Czech WCFB, which encompasses the last five centuries. We also showed unique evidence of Pleistocene landsliding which took place after the termination of the Upper Paleolithic occupation. Finally, we demonstrated the earliest landsliding at the base of the Pleistocene sections that predate considerably the Upper Paleolithic period. No information on exact dates on landsliding between $22 \mathrm{ka}$ cal BP and $1663 \mathrm{AD}$ was available from this area. 


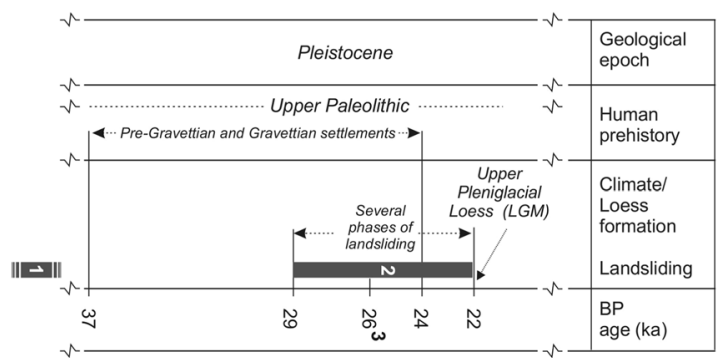

Figure 9. A Pleistocene chronology of landsliding at the Pavlovské vrchy Hills. 1 - the oldest landslides with unknown age, but older than $37 \mathrm{ka} \mathrm{BP}$, which served as a basis for Pre-Gravettian and Gravettian settlements, 2 Several phases of landsliding which affected the Gravettian settlements and caused their relocation within the PVH, 3 - an exactly dated landslide. LGM - Last Glacial Maximum.

The proven age of the active Pleistocene landsliding ranks among the oldest reactivations within the Czech WCFB. Despite the fact that some of the above-mentioned findings were already reported in older works ${ }^{28,29}$, no modern dating methods were available at that time to precisely date both quaternary sediments and remnants of bones. New approaches allowed for the identification of the above-mentioned findings as contemporary with the Gravettian settlements and the age of the Upper Pleniglacial loess which was deposited on the already destroyed Gravettian settlements. While some old landslides in arid and semi-arid regions of the world are still in morphologically distinctive forms, low resistance rocks to denudation together with humid climate of WCFB resulted that the oldest landslides can only be identified using other than direct morphological approaches, e.g. geophysical methods. The Upper Pleniglacial loess fortunately conserved the Gravettian settlements which could therefore be discovered in the twentieth century.

Pleistocene chronology of landsliding. A chronology of landsliding at the Pavlovské vrchy Hills during the Pleistocene can be reconstructed (see Fig. 9) as follows:

1. Basal large-scale landslides of an unknown age, formed by Jurassic limestone scree and redeposited Tertiary silts and marls. They created a versatile paleo-relief of elevations and side-gorges on the slopes of the Pavlovské vrchy Hills. The basal landslides are partially covered by loess and palaeosols.

2. These elevations and plateaus were consequently inhabited by Upper Palaeolithic (particularly Pre-Gravettian and consequently Gravettian) hunters, documented at several sites between 37-24 ka cal BP. The relevant stratigraphy demonstrated that basal landslides (no. 1 in Fig. 9) clearly predate the Upper Palaeolithic period. Details about these findings can be found at the following sites: DV I and II, Pavlov I ${ }^{28,29,38,40,42}$.

3. One of the cases, where a landslide of Tertiary silts and marl created a water-fan, subsequently filled by water molluscs and mammoth bones, was documented in a gorge below the DV II site. The dating and archaeological context are consistent with the large series of dates from the adjacent settlement. A charcoal sample taken from the location of DV II provided a date of $26,100 \pm 200 \mathrm{cal} \mathrm{BP}{ }^{30}$ which can be used for identification of the age of the landsliding.

4. Local landslides within the Gravettian settlements. These events partially destroyed the Gravettian layers and were subsequently covered by later Upper Pleniglacial loess sedimentation. These landslides cannot be dated precisely because they only disintegrated the already deposited cultural layer. They occurred between the end of the settlement and the formation of the cultural beds and the end of the sedimentation of Upper Pleniglacial loess. Related site DV I was described in ${ }^{38,42}$.

Historical records and landsliding. Despite the importance of documentary data for the study of landslides in the Pavlovské vrchy Hills, several uncertainties have to be considered. Some of the original chronicles and other narrative sources were carried away by their authors or their offspring after 1945. A great deal of documentary data was also damaged (both deliberately and unintentional) over the centuries (wars, natural disaster, inappropriate storing, etc.) and their references are known only via early scientific papers and the histories of towns and villages. The landslides usually did not attract the attention of chroniclers if they did not cause any economic losses. Most of the reports described the occurrence of landslides only briefly and more detailed accounts appeared as of the second half of the eighteenth century. The oldest accounts therefore made the exact localization of landslides impossible in some cases and the same uncertainty was related to the determination of the exact date when the landslide occurred. More recent documentary data did not have to be more accurate, however, than the older one and had to be checked carefully. Finally, except for the different informational value of documentary data, the repeating damages at the same localities and same buildings, which were continuously repaired, made it more difficult to determine the accurate extent of the damage. Despite all these uncertainties, documentary evidence is valuable and an indispensable source of data describing the occurrence as well as the consequences of landslides in the Pavlovské vrchy Hills during the last four centuries. The last stage of the sliding activity in the Pavlovské vrchy Hills was documented in 2014, when there was a great deal of damage to the road infrastructure. The cause of this activity was the high rainfall value in September 2014. Engineering-geological works provided 
data on the actual extent and depth of slope deformations (Fig. 3), but the activity was recorded outside archaeological sites. No landslides were recorded here between 1941 and 2014. The current state of landsliding in the area of Pavlovské vrchy Hills was identified using detailed field mapping and LIDAR data analysis.

\section{Conclusions}

We studied the chronology of landsliding at the Pavlovské vrchy Hills (Czech part of the WCFB). Leaving aside the evidence of earlier landsliding in the subsoil, the findings about repeated landsliding, presented in this work, can be used as an example of landslide recurrence persisting from the Upper Pleistocene to the present. This work thereby provided new information about landsliding in the Czech WCFB. The main contribution of this work can be summarized as follows:

- We analyzed available geochronological data, related to the archaeological excavations, which helped us identify several previously unknown phases of landsliding from the Czech part of the WCFB.

- An indirect dating of landslides which destroyed the cultural Gravettian beds was further based on the known age at the base of the Upper Pleniglacial loess which conserved both the landslides and the settlements.

- The identification of the 1663 landslide in the village of Pavlov is thus the oldest landslide in Czech WCFB from the historical period, and the fourth oldest landslide in CR, dated using documentary data.

- Compilation of the chronology of landsliding (see Table 1) for the Pavlovské vrchy Hills between as the seventeenth century and information about related losses from landsliding.

Received: 23 August 2019; Accepted: 31 December 2019;

Published online: 22 January 2020

\section{References}

1. Kirchner, K., Máčka, Z., Krejčí, O. \& Bíl, M. Slope movements in the Eastern Moravia (Outer Western Carpathians. Acta Universitatis Carolinae: Geographica supplementum 35, 133-143 (2000).

2. Krejčí, O. et al. Slope movements in the Flysch Carpathians of Eastern Czech Rep. Triggered by Extreme Rainfals in 1997: A Case Study. Phys. Chem. Earth. 36, 1567-1576 (2002).

3. Bíl, M. \& Müller, I. The origin of shallow landslides in Moravia (Czech Republic) in the spring of 2006. Geomorphology 99, 246-253 (2008).

4. Pánek, T. et al. Catastrophic slope failure and its origins: case of the May 2010 Girová Mountain long-runout rockslide (Czech Republic). Geomorphology 130, 352-364 (2011).

5. Klimeš, J. \& Blahůt, J. Landslide risk analysis and its application in regional planning: an example from the highlands of the Outer Western Carpathians, Czech Republic. Nat Hazards 64, 1779-1803 (2012).

6. Holec, J. et al. A small-scale landslide susceptibility assessment for the territory of Western Carpathians. Nat. Hazards 69, 1081-1107 (2013).

7. Bíl, M. et al. A Chronology of Landsliding and its Impacts on the Village of Halenkovice, Outer Western Carpathians. Geography 119, 342-363 (2014).

8. Bíl, M. et al. Total water content thresholds for shallow landslides, Outer Western Carpathians. Landslides 13,337-347 (2016)

9. Klimeš, J. et al. Investigation of recent catastrophic landslides in the flysch belt of Outer Western Carpathians (Czech Republic): progress towards better hazard assessment. Nat. Hazards Earth Syst. Sci. 9, 119-128 (2009).

10. Baroň, I., Řehánek, T., Vošmik, J., Musel, V. \& Kondrová, L. Report on a recent deep-seated landslide at Gírová Mt., triggered by a heavy rainfall: Outer West Carpathians; Czech Republic. Landslides 8, 355-361 (2011).

11. Baroň, I., Cílek, V., Krejčí, O., Melichar, R. \& Hubatka, F. Structure and dynamics of deep-seated slope failure in the Magura Flysch Nappe, Outer Western Carpathians (Czech Republic). Nat. Hazards Earth Syst. Sci. 4, 549-562 (2004).

12. Baroň, I., Agliardi, F., Ambrosi, C. \& Crosta, G. B. Numerical analysis of deep-seated mass movements in the Magura Nappe; Flysch Belt of the Western Carpathians (Czech Republic). Nat. Hazards Earth Syst. Sci. 5, 367-374 (2005).

13. Stemberk, J., Hartvich, F., Blahút, J., Rybář, J. \& Krečí, O. Tectonic strain changes affecting the development of deep seated gravitational slope deformations in the Bohemian Massif and Outer Western Carpathians. Geomorphology 289, 3-17 (2017).

14. Brázdil, R. et al. The influence of meteorological factors on rockfall in the Moravskoslezské Beskydy Mts. Geografie 117, 1-20 (2012).

15. Šilhán, K. et al. Evaluation of meteorological controls of reconstructed rockfall activity in the Czech Flysch Carpathians. Earth Surf. Proc. Land. 36, 1898-1909 (2011).

16. Šilhán, K., Pánek, T. \& Hradecký, J. Implications of spatial distribution of rockfall reconstructed by dendrogeomorphological methods. Nat. Hazards Earth Syst. Sci. 13, 1817-1826 (2013).

17. Pánek, T., Smolková, V., Hradecký, J., Baroň, I. \& Šilhán, K. Holocene reactivations of catastrophic complex flow-like landslides in the Flysch Carpathians (Czech Republic/Slovakia). Quat. Res. 80, 33-46 (2013).

18. Krejčí, O., Hubatka, F. \& Švancara, J. Gravitational spreading of the mountain ridges in the Moravian-Silesian Beskids. Acta Geodyn. Geomater. 135, 97-109 (2004).

19. Hradecký, J. \& Pánek, T. Deep-seated gravitational slope deformations and their influence on consequent mass movements (case studies from the highest part of the Czech Carpathians). Nat. Hazards 45, 235-253 (2008).

20. Margielewski, W. Records of the late Glacial-Holocene palaeoenvironmental changes in landslide forms and deposits of the Beskid Makowski and Beskid Wyspowy Mts. area (Polish Outer Carpathians). Folia Quaternaria 76, 1-149 (2006).

21. Pánek, T. et al. Large Late Pleistocene landslides from the marginal slope of the Flysch Carpathians. Landslides 11, 981-992 (2014).

22. Jankovská, V., Baroň, I., Nývlt, D., Krejčí, O. \& Krejčí, V. Last Glacial to Holocene vegetation succession recorded in polyphase slopefailure deposits on the Maleník Ridge, Outer Western Carpathians. Quat. Int. 470, 38-52 (2018).

23. Špůrek, M. Historical catalogue of slide phenomena. Geografický ústav ČSAV, Brno (1972).

24. Rybář, J. The impact of climatic effects to landsliding and other dangerous slope movement. In: Barvínek, R. (ed) Quido Záruba 1899-1993. Zakladatel československé inženýrské geologie. Geotechnické dny. Praha, pp. 34-45 (1999).

25. Guzzetti, F., Ardizzone, F., Cardinali, M., Rossi, M. \& Valigi, D. Landslide volumes and landslide mobilization rates in Umbria, central Italy. Earth Planet. Sci. Lett. 279, 222-229 (2009).

26. Raška, P., Klimeš, J. \& Dubišar, J. Using local archive sources to reconstruct historical landslide occurrence in selected urban regions of the Czech Republic: Examples from regions with different historical development. Land Degrad. Develop. 26, 142-157 (2015).

27. Raška, P., Zábranský, V., Brázdil, R. \& Lamková, J. The late Little Ice Age landslide calamity in North Bohemia: Triggers, impacts and post-landslide development reconstructed from documentary data (case study of the Kozí vrch Hill landslide). Geomorphology 255, 95-107 (2016). 
28. Knor, A., Ložek, V., Pelíšek, J. \& Žebera, K. Dolní Věstonice. Výzkum tábořiště lovců mamutů v letech 1945-1947. Nakladatelství Československé akademie věd, Praha (1953).

29. Klíma, B. Dolní Věstonice. Výzkum tábořiště lovců mamutů v letech 1947-1952. Nakladatelství Československé akademie věd, Praha (1963).

30. Svoboda, J. et al. Pleistocene landslides and mammoth bone deposits: The case of Dolní Věstonice II, Czech Republic. Geoarchaeology 2019, 1-14 (2019).

31. Pánek, T., Miklín, J. \& Kirchner, K. Limestone Klippen of the Pavlov Hills. In: Pánek, T. \& Hradecký, J. (eds) Landscapes and Landforms of the Czech Republic. World Geomorphological Landscapes. Springer, Cham, pp 373-384 (2016).

32. Picha, F. J., Stráník, Z. \& Krejčí, O. Geology and Hydrocarbon Resources of the Outer Western Carpathians and Their Foreland, Czech Republic. In: Golonka, J, Picha, F. J. (eds) The Carpathians and Their Foreland: Geology and Hydrocarbon Resources. AAPG Memoir, Tulsa, pp 49-175 (2006).

33. Poul, I., Melichar, R. \& Janečka, J. Thrust tectonics of the Upper Jurassic limestones in the Pavlov Hills (Outer Western Carpathians, Czech Republic). In: Poblet, J., Lisle, R. J. (eds) Kinematic Evolution and Structural Styles of Fold-and-Thrust Belts. Special Publications 349. Geological Society, London, pp. 237-248 (2011).

34. Rybář, J. Basic geological structures conditioning evolution of landslide movements-Example from Czech Republic. In: Senneset, K. (ed) Landslides-Glissements de terrain, vol. 3. A.A. Balkema, Rotterdam, pp 1961-1965 (1996).

35. Havlíček, P. \& Kovanda, J. Nové výzkumy kvartéru v okolí Pavlovských vrchů. Sborník geologických věd A - Anthropozoikum 16, 21-59 (1985).

36. Havlíček, P. \& Smolíková, L. Geological context. In: Svoboda, J. (ed) Dolní Věstonice II. Chronostratigraphy, Paleoethnology, Palaeoanthropology. The Dolní Věstonice Studies 21. Institute of Archaeology of the CAS, Brno, pp 62-70 (2016).

37. Antoine, P. et al. High-resolution record of the environmental response to climatic variations during the Last Interglacial-Glacial cycle in Central Europe: the loess-palaeosol sequence of Dolní Věstonice (Czech Republic). Quat. Sci. Rev. 67, 17-38 (2013).

38. Klíma, B. Dolní Věstonice - tábořiště lovců mamutů. Academia, Praha (1983).

39. Svoboda, J. Dolní Věstonice-Pavlov. Academia, Praha (2016).

40. Svoboda, J. et al. Excavations 1990-1993. Přehled výzkumů 59, 35-67 (2018).

41. Svoboda, J. II. Settlement units and human fossils Spatial content, stratigraphies, and chronology. In: Svoboda, J. (ed) Dolní Věstonice II. Chronostratigraphy, paleoethnology, paleoanthropology. The Dolní Věstonice Studies 21. Institute of Archaeology of the CAS, Brno, pp 16-48 (2016).

42. Svoboda, J., Novák, M., Sázelová, S. \& Demek, J. Pavlov I: A large Gravettian site in space and time. Quaternary International 406, 95-105 (2016).

43. Reimer, P. J. et al. IntCal13 and Marine13 radiocarbon age calibration curves 0-50,000 years cal BP. Radiocarbon 55, 1869-1887 (2013).

44. Fuchs, M., Kreutzer, S., Russeau, D. D., Antoine, P. \& Hatté, C. The loess sequence of Dolní Věstonice, Czech Republic: A new OSL - based chronology of the Last Climatic Cycle. Boreas 42, 664-677 (2013).

45. Fewlass, H. et al Direct radiocarbon dates of mid Upper Palaeolithic human remains from Dolní Věstonice II and Pavlov I, Czech Republic. Journal of Archaeological Science: Reports 27 (2019).

46. Clark, U. P. \& Mix, A. C. Ice sheets and sea level of the Last Glacial Maximum. Quat. Sci. Rev. 21, 1-7 (2002).

47. Rehfeld, K., Münch, T., Ho, S. L. \& Laepple, T. Global patterns of declining temperature variability from the Last Glacial Maximum to the Holocene. Nature 554, 356-359 (2018).

48. Antoine, P. et al. Loess-palaeosol sequence DV-09 (Dolní Věstonice brickyard). Chronostratigraphy and paleoenvironments. In: Svoboda, J. (ed) Dolní Věstonice II. Chronostratigraphy, paleoethnology, paleoanthropology. The Dolní Věstonice Studies 21. Institute of Archaeology of the CAS, Brno, pp 49-61 (2016).

49. Frechen, M., Ochesb, E. A. \& Kohfeld, K. E. Loess in Europe - mass accumulation rates during the Last Glacial Period. Quat. Sci. Rev. 22, 1835-1857 (2003)

50. Klíma, B. Nálezy ze štěrkovny u Strachotína (okr. Břeclav). Přehled výzkumů. 197078 (1971)

51. Podborský, V. Pravěké dějiny Moravy. Muzejní a vlastivědná společnost, Brno. (1993).

52. Tejral, J. Doba římská v oblastní vodního díla. In: Oblast vodního díla Nové Mlýny od pravěku do středověku. Archeologický ústav Akademie věd České republiky, Brno, (2002).

53. Tejral, J. K. langobardskému odkazu v archeologických pramenech na území Československa. Slovenská Archeologia 23, 379-432 (1975).

54. Stuchlík, S. Oblast vodního díla Nové Mlýny od pravěku do středověku. Archeologický ústav Akademie věd České republiky, Brno (2002).

55. Bělina, P. Kronika Českých zemí. Fortuna Libri, Praha (2012).

56. Hungr, O., Leroueil, S. \& Picarelli, L. Varnes classsification of landslide types, an update. In: Eberhardt, E., Froese, C., Turner, K. \& Leroueil, S. (eds) Landslides and Engineered Slopes: Protecting Society through Improved Understanding. Proceedings of the 11th International Symposium on Landslides and 2nd North American Symposium on Landslides (Banff, Alberta, Canada, 2-8 June 2012). Taylor Francis Group, London, pp 47-58 (2012).

57. Crosta, G. B. \& Zanchi, A. Deep-seated slope deformations. Huge, extraordinary, enigmatic phenomena. In: Bromhead, E, Dixon, N, \& Ibsen, M. (eds) Landslides in Research, Theory and Practice. Thomas Telford, London, pp 351-358 (2000).

58. Janovský, J. Inženýrskogeologické poměry sesuvného území mezi Dolními Věstonicemi a Pavlovem. GEOtest, a. s., Brno. (1967).

59. Maca, J. Pollauer Heimatbuch: 1334-1946: Geschichte und Schicksal einer deutschen Gemeinde in Südmähren. Selbstverlag, Wien (1994).

60. Lederer, H. Unter-Tannowitz, Pollauer Berge, Südmähren, Weinviertel: gesammelte Aufsätze von Prof. Hans Lederer über seine Heimat. K. Sax, Roden (2012).

61. Wolny, G. Die Markgrafschaft Mähren. Brünner Kreis I. Selbstverlag des Verfassers, Brno (1836).

62. Jüttner, K. Die erdgeschichtliche Entwicklung des Bodens der Gemeinde Pollau. Deutsch-mähr.-schles. Heimat 23, 1-6 (1937).

63. Kryčer, R. Dějiny obcí Bavory, Bulhary, Klentnice, Mušov, Pavlov, Perná, Sedlec, Dolní Věstonice, Horní Věstonice. SOkA Břeclav (undated document).

64. MZA Brno, F 18 Hlavní registratura Ditrichštejnů Mikulov (1249) 1411-1888, inv. č. 9009, Senkung des Pollauer Berges, kart. (1586).

65. Woldřich, J. \& Stejskal, J. Geologický profil hliništěm a svážení v cihelně u Dolních Věstonic na Moravě. Věda přírodní: měsičník pro šiření a pěstování věd přirodních: časopis pro přirodovědeckou vlastivědu. Zvláštní otisk z časopisu Věda přirodní 15, 129-137 (1934).

66. Dobrovolný, P., Brázdil, R., Trnka, M., Kotyza, O. \& Valášek, H. Precipitation reconstruction for the Czech Lands, AD 1501-2010. Int. J. Climatol. 35, 1-14 (2015).

67. Večeřová, J. \& Gregor, A. Hodinové záznamy vzdušných srážek na meteorologické observatoři české techniky v Brně za léta 1912-1922. Práce Moravské přírodovědecké společnosti, VII, Brno (1932).

68. Brázdil, R. et al. Drought in the Czech Lands: past, present and future. Global Change Research Institute CAS, Brno (2015). 


\section{Acknowledgements}

This work was prepared with the help of a project undertaken by the Transport Research Centre (OP R\&D for Innovation No. CZ.1.05/2.1.00/03.0064), project LO1610. We would also like to thank Jiř́ and Tomáš Sedoník and Soňa Chmelíková for their help with documentary data preparation and David Livingstone for assistance with language editing. We also appreciate the comments and suggestions provided by the two anonymous reviewers.

\section{Author contributions}

M.B., O.K., L.D. a J.S. wrote the main manuscript text, V.K. and J.M. prepared figures, L.D. conducted documentary data survey, J.S. carried out archaeological survey. All authors reviewed the manuscript

\section{Competing interests}

The authors declare no competing interests.

\section{Additional information}

Correspondence and requests for materials should be addressed to M.B.

Reprints and permissions information is available at www.nature.com/reprints.

Publisher's note Springer Nature remains neutral with regard to jurisdictional claims in published maps and institutional affiliations.

(c) Open Access This article is licensed under a Creative Commons Attribution 4.0 International

License, which permits use, sharing, adaptation, distribution and reproduction in any medium or format, as long as you give appropriate credit to the original author(s) and the source, provide a link to the Creative Commons license, and indicate if changes were made. The images or other third party material in this article are included in the article's Creative Commons license, unless indicated otherwise in a credit line to the material. If material is not included in the article's Creative Commons license and your intended use is not permitted by statutory regulation or exceeds the permitted use, you will need to obtain permission directly from the copyright holder. To view a copy of this license, visit http://creativecommons.org/licenses/by/4.0/.

(C) The Author(s) 2020 